\title{
Continental atmospheric circulation over Europe during the Little Ice Age inferred from grape harvest dates
}

\author{
P. Yiou ${ }^{1}$, I. García de Cortázar-Atauri ${ }^{2,}{ }^{*}$, I. Chuine ${ }^{2}$, V. Daux ${ }^{1}$, E. Garnier ${ }^{1,3}$, N. Viovy ${ }^{1}$, C. van Leeuwen ${ }^{4}$, \\ A. K. Parker ${ }^{4, *}$, and J.-M. Boursiquot ${ }^{5,6}$ \\ ${ }^{1}$ Laboratoire des Sciences du Climat et de l'Environnement, UMR8212, CEA-CNRS-UVSQ, \\ CE Saclay l'Orme des Merisiers, 91191 Gif-sur-Yvette, France \\ ${ }^{2}$ Equipe BIOFLUX, Centre d'Ecologie Fonctionnelle et Evolutive, CNRS, 1919 route de Mende, \\ 34293 Montpellier cedex 05, France \\ ${ }^{3}$ Centre de Recherche en Histoire Quantitative, UMR Université de Caen - CNRS, Esplanade de la Paix, \\ 14032 Caen cedex 5, France \\ ${ }^{4}$ ENITA, Université de Bordeaux, UMR EGFV, ISVV, 1 Cours du Général de Gaulle, CS 40201, \\ 33175 Gradignan-cedex, France \\ ${ }^{5}$ Montpellier SupAgro - INRA, UMR DIAPC 1097, Equipe Génétique Vigne, 2 place Viala, 34060 Montpellier, France \\ ${ }^{6}$ INRA Unité Expérimentale du Domaine de Vassal, route de Sète, 34340 Marseillan Plage, France \\ *present address: INRA-Agroclim, Domaine St Paul - Site Agroparc 84914 Avignon, France \\ ** present address: Lincoln University, P.O. Box 84, Lincoln 7647, New Zealand \\ Correspondence to: P. Yiou (pascal.yiou@1sce.ipsl.fr)
}

Received: 23 July 2011 - Published in Clim. Past Discuss.: 27 September 2011

Revised: 8 February 2012 - Accepted: 9 February 2012 - Published: 19 March 2012

\begin{abstract}
Estimates of climate conditions before the 19th century are based on proxy data reconstructions or sparse meteorological measurements. The reconstruction of the atmospheric circulation that prevailed during the European Little Ice Age $(\sim 1500-1850)$ has fostered many efforts. This study illustrates a methodology, combining historical proxies and modern datasets to obtain detailed information on the atmospheric circulation that prevailed over the North Atlantic region during the Little Ice Age. We used reconstructions of temperature gradients over France based on grape harvest dates to infer the atmospheric circulation. We found that blocking situations were more likely in summer, inducing a continental atmospheric flow. This study advocates that the reconstructions of the past atmospheric circulation should take this regime into account.
\end{abstract}

\section{Introduction}

The climate anomaly of the Little Ice Age (LIA) affected most of the European population between 1500 and 1850 . This period underwent a few multidecadal episodes of anomalously cold temperatures that jeopardized crops and public health (Le Roy Ladurie, 1971). There have been several attempts to estimate the features of the atmospheric circulation during that period (Jacobeit et al., 2003; Jones et al., 1999; Luterbacher et al., 2000, 2002; Slonosky et al., 2001; Trouet et al., 2009; Briffa et al., 1986, 1987). Some studies have relied on the relationship between the atmospheric circulation and surface temperature or other proxy records (Briffa et al., 1986; Souriau and Yiou, 2001; Luterbacher et al., 1999, 2000). A major challenge to investigate this period is the rarity of reliable meteorological measurements before the 18th century. Historical archives provide direct testimonies of such events and their impacts on society and the environment (Brazdil et al., 2005; Kuettel et al., 2010). 
An important task is then to translate them into quantitative climate variables.

The methodology to assess the features of the atmospheric flow is based on the temperature gradient reconstructions. The relation between the atmospheric circulation and surface conditions has been investigated by many authors (Luterbacher et al., 1999; Folland et al., 2009; Souriau and Yiou, 2001; Trouet et al., 2009). Indices of circulation, such as the North Atlantic Oscillation index, have been used to establish such dependence and it has been argued that the atmospheric circulation can be inferred from surface temperature or precipitation observations through such indices (Briffa et al., 1987). Here, we exploit the relation between present temperature patterns and large-scale circulation over the North Atlantic. We use this relation to infer pressure patterns in periods of specific reconstructed temperature gradients.

In this paper, we used a new extensive database of historical grapevine harvest dates (GHD), covering France and Switzerland during the past centuries, to reconstruct atmospheric conditions during the LIA (Daux et al., 2011). This dataset was built by a team of climatologists, historians, agronomists and ecophysiologists (see list of co-authors). Important contributions of this new database are its spatial coverage and its position in a socio-historical context (Garnier et al., 2010) that allow access to information about regional climate.

\section{Data and method}

\subsection{Historical grape harvest dates}

We used eight original datasets of West European grapevine harvest dates (GHD), including seven in France (Bordeaux, Loire Valley, Rhône Valley, Île-de-France, Alsace, Burgundy and Jura) and one in Switzerland (Lac Léman). Each series was constructed from an ensemble of harvest dates recorded at different sites. When documentary sources from several vine growers were available for the same period, grapevine harvest dates were obtained as the median date among all available standardized dates, including a reference series (Table 1 in Supplement) following the methodology developed by Chuine et al. (2004). The number of available GHD observations for each region is reported in Fig. 1a. For each GHD series, a precise identification of the grapevine varieties cultivated was carried out based on the expertise and grapevine varieties database of the INRA "Domaine de Vassal" (http://bioweb.ensam.inra.fr/collections_vigne/), and on old literature available in the European and French digital libraries (Europeana; http://www.europeana.eu; Gallica; http: //www.gallica.fr) and Google Books (http://books.google.fr) (Guyot, 1868c, a, b; Jullien and Jullien, 1866; Odart, 1845; Galet, 1956, 2004, 2006). Datasets were classified according to regional and historical agriculture criteria (Jullien and Jullien, 1866; Guyot, 1868c, a, b; Odart, 1845) such as the geo- graphical structure of the vineyard, the viticultural practices and the varieties cultivated. As García de Cortázar-Atauri et al. (2010) showed, variety and agricultural information are particularly important for the accuracy of climate reconstructions using grapevine harvest dates. For example, eastern series were separated into three series: Jura, Burgundy and Switzerland, because even if these regions are not very far apart (within $75 \mathrm{~km}$ ), there are important differences in the cultivated varieties (Table 1 in Supplement). A complete and detailed description of the grape harvest date dataset used in this study can be found in a companion paper (Daux et al., 2011).

The standard error due to the number of available series within each region and their consistency is proportional to the standard deviation of the series and weighed by the square root of the number of available observations each year. This standard error is shown in Fig. $1 b$.

For calibration and comparison purposes, we used temperature observations over the 20th century from the ECA\&D data base (Klein-Tank et al., 2002) for Switzerland and from Météo-France (O. Mestre, personal communication, 2008) for France. The breakpoints in French temperature data were documented from available metadata information (S. Jourdain and O. Mestre, Météo-France, personal communication, 2008). The series were homogenized by a procedure of Caussinus and Mestre(2004).

\subsection{Phenology model}

To construct and validate the process-based phenological models used to reconstruct temperature anomalies from GHDs, an important dataset of contemporary phenological observations of grapevine was used. This database contains more than 2000 phenological observations for each main phenological stage (budbreak, flowering, veraison) coming from different places in France, Switzerland and Italy and for around 100 grapevine varieties (Parker et al., 2011).

The process-based phenological model used was presented in García de Cortázar-Atauri et al. (2010). The model describes two independent phases: the first phase calculates veraison date, and the second one goes from veraison to harvest date.

The first phase is modeled using the model of Wang and Engel (1998) which has four parameters: a minimum, optimum and maximum temperature $\left(T_{\min }, T_{\mathrm{opt}}, T_{\max }\right)$ and a threshold of cumulated temperature actions $\left(F^{*}\right)$ (dimensionless). The date of veraison is such that

$$
\begin{aligned}
& F^{*}=\sum_{t=t_{0}}^{t_{\text {veraison }}} \operatorname{RF}\left(T_{t}\right), \\
& \operatorname{RF}\left(T_{t}\right)=\left\{\begin{array}{l}
\frac{2\left(T_{t}-T_{\min }\right)^{\alpha}\left(T_{\mathrm{opt}}-T_{\min }\right)^{\alpha}-\left(T_{t}-T_{\min }\right)^{2 \alpha}}{\left(T_{\mathrm{opt}}-T_{\min }\right)^{2 \alpha}} \text { if } T_{\min } \leq, T_{t} \leq T_{\max } \\
0 \text { if } T_{t}<T_{\min } \text { or } T_{t}>T_{\max } .
\end{array}\right.
\end{aligned}
$$

In Eq. (1), the parameter $\alpha$ is

$$
\alpha=\frac{\log 2}{\log \left[\frac{\left(T_{\max }-T_{\min }\right)}{\left(T_{\mathrm{opt}}-T_{\min }\right)}\right]} .
$$



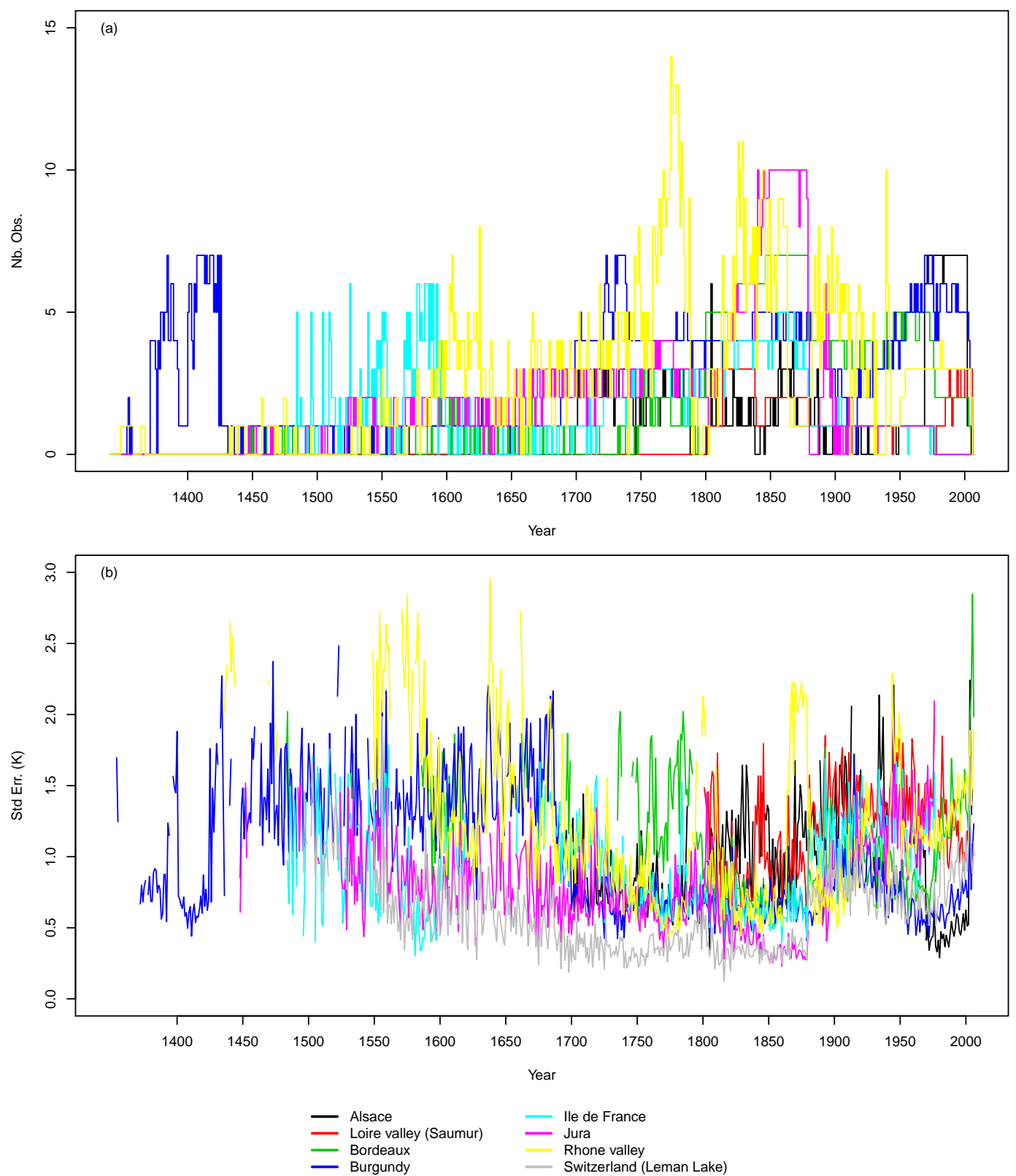

Fig. 1. (a) Number of observations for each viticulture region and for each year. (b) Standard error of the temperature reconstruction for each viticulture region, taking into account the standard deviation within regions and the number of available records.

The date $t_{0}$ is the day when rates of forcing (RF) accumulation starts and was optimized using all veraison dates available for grapevine in the database. Its estimate was 15 March, which is close to values found in previous studies on grapevine phenology (Williams et al., 1985; Nendel, 2009; Parker et al., 2011) and it was fixed the same for all varieties. Cardinal temperatures $T_{\min }$ and $T_{\max }$ were fixed at $0{ }^{\circ} \mathrm{C}$ and $40^{\circ} \mathrm{C}$, respectively (Champagnol, 1984; Jones, $2003)$ and $T_{\mathrm{opt}}$ and $F^{*}$ were optimized for each variety, respectively. Note that the RF expression in Eq. (1) limits the vine growth when temperature exceeds $T_{\mathrm{opt}}$, which depends on the vine type. The inversion method uses the mean daily temperature of the reference period in each region and calculates the anomaly value for each year. Thus, the quality and the uncertainty of the anomaly calculated depend on those already measured for the model, which depend on the vineyard and the variety (the values vary between 6.1 and 10.5). The model quality obtained in this study is similar or better compared to errors obtained in other works about grapevine phenology. Table 2 in Supplementary Information provides parameters and statistical indicators of the model accuracy (efficiency, confidence intervals and root mean square error) 
for each variety identified in each region. These values were used to determine the accuracy of the model and to calculate the uncertainties related to the anomaly reconstruction.

The veraison-harvest period was described by a fixed number of days ( $N$, Table 3 in Supplement). This duration is generally not constant, but its standard deviation does not exceed 3 days (García de Cortázar-Atauri et al., 2010). Each value was related to the vineyard (varieties, style of wine), the agricultural practices and the crop state (water, carbon and nitrogen balances) (Jones, 2003; Holt et al., 2008; García de Cortázar-Atauri et al., 2010). In this study, this constant and the possible error due to cultural practices and climate conditions, were obtained using combined information of two different sources, our phenological database, and a mechanistic generic crop model, STICS (http://www.avignon.inra. fr/agroclim_stics) (Brisson et al., 1998, 2002, 2003, 2009), adapted to the grapevines (García de Cortázar-Atauri, 2006). The STICS crop model is a daily time-step model that simulates crop growth, soil water and nitrogen balances driven by daily climatic data. The annual development of grapevine in the model is described by the main phenological stages (Jones, 2003; García de Cortázar-Atauri et al., 2009b). To simulate biomass growth, the STICS model uses nitrogen and carbon reserves of the grapevine and takes into account competition between vegetative and reproductive organs. The fruit growth is described by the dynamics of dry matter accumulation and water content (García de Cortázar-Atauri et al., 2009a; Brisson et al., 2009). To assess the uncertainty generated by past technical practices and not only by thermal climate variables, a range of input was provided to the STICS crop model: representative regional soil characteristics (field capacity, wilting point and bulk density) (García de CortázarAtauri, 2006; Brisson et al., 2009) and the STICS crop soils database: http://www.avignon.inra.fr/agroclim_stics), historical technical conditions described in old references (plant density, row orientation, canopy geometry, fruit load, nitrogen fertilization, trimming date) (Guyot, 1868c, a, b; Bidet, 1759a, b; de Serres, 1600; Jullien and Jullien, 1866), quality description and harvest decision (based on sugar content reached at harvest) (de Serres, 1600; Estienne and Liebault, 1589; Chaptal, 1801; de Herrera and Real Sociedad Económica Matritense, 1818; Gay-Lussac, 1828; Laudier, 1852; Maumene, 1858; Gautier, 1891), variety information (Odart, 1845; Rendu, 1857; Jullien and Jullien, 1866; Galet, $1956,2004,2006)$ and daily weather data (maximum and minimum temperatures, rainfall, radiation, wind and humidity) (INRA Agroclim database). Their analysis provided an estimation of the uncertainty on grape harvest date linked to cultural practices and non thermal climate variables (Table 3 in Suplement) (García de Cortázar-Atauri et al., 2010). We implicitly assumed that the genetic and physiological properties of vine are stationary through time, because none of the agronomy archives mention such changes. This is a generic assumption (although not necessarily formulated) in all climate proxy reconstructions.
The daily mean temperature of the closest weather station (within $5 \mathrm{~km}$ radius) was used for the parameterization of the process-based phenological model. Mean temperature was calculated as the arithmetic mean between the daily minimal and maximal temperatures.

The methodology developed by Chuine et al. (2004) was used to reconstruct temperature anomalies from the nine composite series. Temperature anomalies were determined with respect to a reference temperature (15 March-31 August mean temperature of the 1960-1989 periods) by inverting the process-based phenological models. The inversion consisted of fitting the average anomaly temperature that would provide the observed past harvest date with the phenological model. Temperature anomalies correspond to the 15 March to 31 August period and were calculated for all the varieties that were grown during the period investigated in each region. The final temperature anomaly of a region was calculated as the arithmetic mean of all anomalies obtained with the different varieties of this region.

\section{Results}

\subsection{Grape harvest dates and temperature reconstructions}

From the set of nine reconstructed temperature anomalies, we selected four groups of vineyards corresponding to the four cardinal regions of France (Bordeaux and Loire Valley for the West, Burgundy, Jura and Switzerland for the East, Rhône Valley for the South and Île-de-France and Alsace for the North). These four regions were chosen to estimate meridional and zonal temperature gradients.

We chose to study gradients of temperature (rather than gradients of temperature anomalies). This does not alter the inferred dynamics and provides a better physical intuition on the thermal differences. The temperatures series for each cardinal region are reconstructed by adding the mean temperature anomaly of the region to the average temperature of the 15 March-31 August period over 1960-1990 of a reference weather station. The reference weather station for the North was Paris, Orange for the South, Bordeaux for the West and Dijon for the East. Hence, the temperature gradients are obtained from the temperature reconstructions.

The temperature anomaly reconstructions and observations are shown in Fig. 2. In each cardinal region, there is a good agreement between the temperature anomalies reconstructed in the different vineyards and temperature anomaly observations over the 1950-2000 period, with correlation coefficients $r$ always exceeding 0.76 ( $p$ values $<10^{-11}$ ). The correlation coefficients still exceed 0.67 ( $p$ values $<10^{-13}$ ) over 1900-1950, except in the south of France, where $r=$ $0.57\left(p\right.$ values $\left.<10^{-9}\right)$. GHD-based temperature anomaly reconstructions (Fig. 2) generally yield interdecadal fluctuations that are consistent with estimates from other proxy 


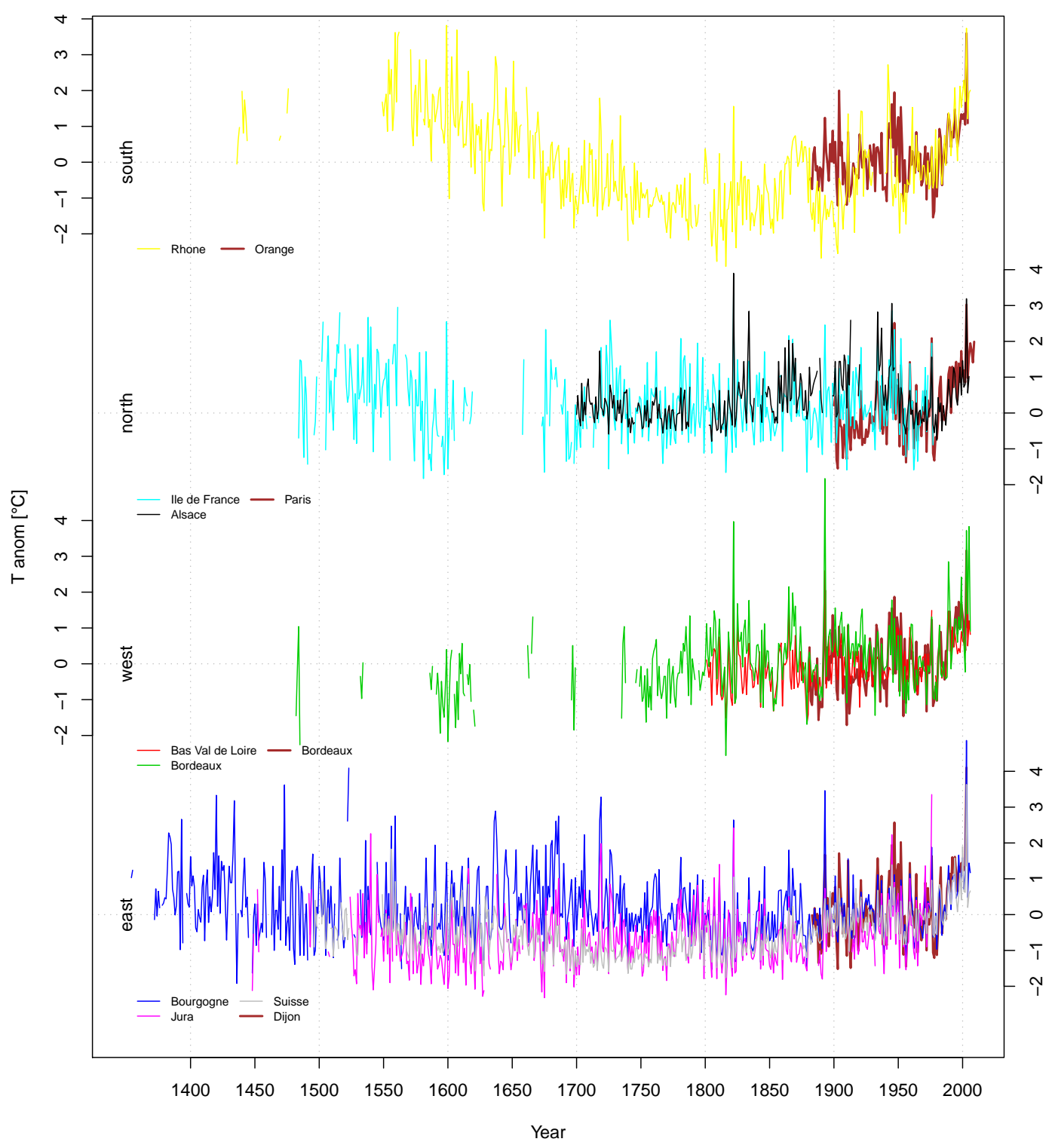

Fig. 2. Reconstructed temperature anomalies of the mid-March to August temperature deduced from GHD in four French regions (South, North, West and East: thin lines). Heavy brown lines indicate observed temperature anomalies from the ECA\&D database (Klein-Tank et al., 2002) and homogenized data from Météo-France (O. Mestre, personal communication, 2008) for Orange, Paris, Bordeaux and Dijon cities.

records (Guiot et al., 2005; Maurer et al., 2009; Meier et al., 2007).

The grapevine varieties vary from one region to another as a response to local climate and soil characteristics (Van Leeuwen and Seguin, 2006). The timing of grape harvests has been regulated and scheduled on a local level, generally by groups of experts (mainly winegrowers) from the area (de La Poix de Fréminville, 1758; Pocquet de Livonnière, 1733; Salvaing de Boissieu, 1664). Even if agricultural practices from one region could cross its borders, each region shows specific particularities (Guyot, 1868d). Hence, it is remarkable that Rhône valley harvest data series has a similar behavior as the Languedoc dataset (data not shown, Daux et al.,
2011), showing a decreasing trend in reconstructed temperatures between 1600 and 1700, unlike those at the other cardinal regions. The analysis of various agriculture-viticulture books edited before the 19th century does not show major differences, nor significant revolutions in vineyard management for the period studied in those vineyards (Alonso de Herrera, 1513; Estienne and Libeault, 1589; de Serres, 1600; Bidet, $1759 \mathrm{c})$. Moreover, the decreasing temperature trend in Southern France between 1600 and 1700 is also found in other studies in the same region (Guiot et al., 2005; Maurer et al., 2009). We conjecture that the discrepancy between the reconstructed and observed temperature anomalies in Southern France in 1880-1920 is due to a low number of 


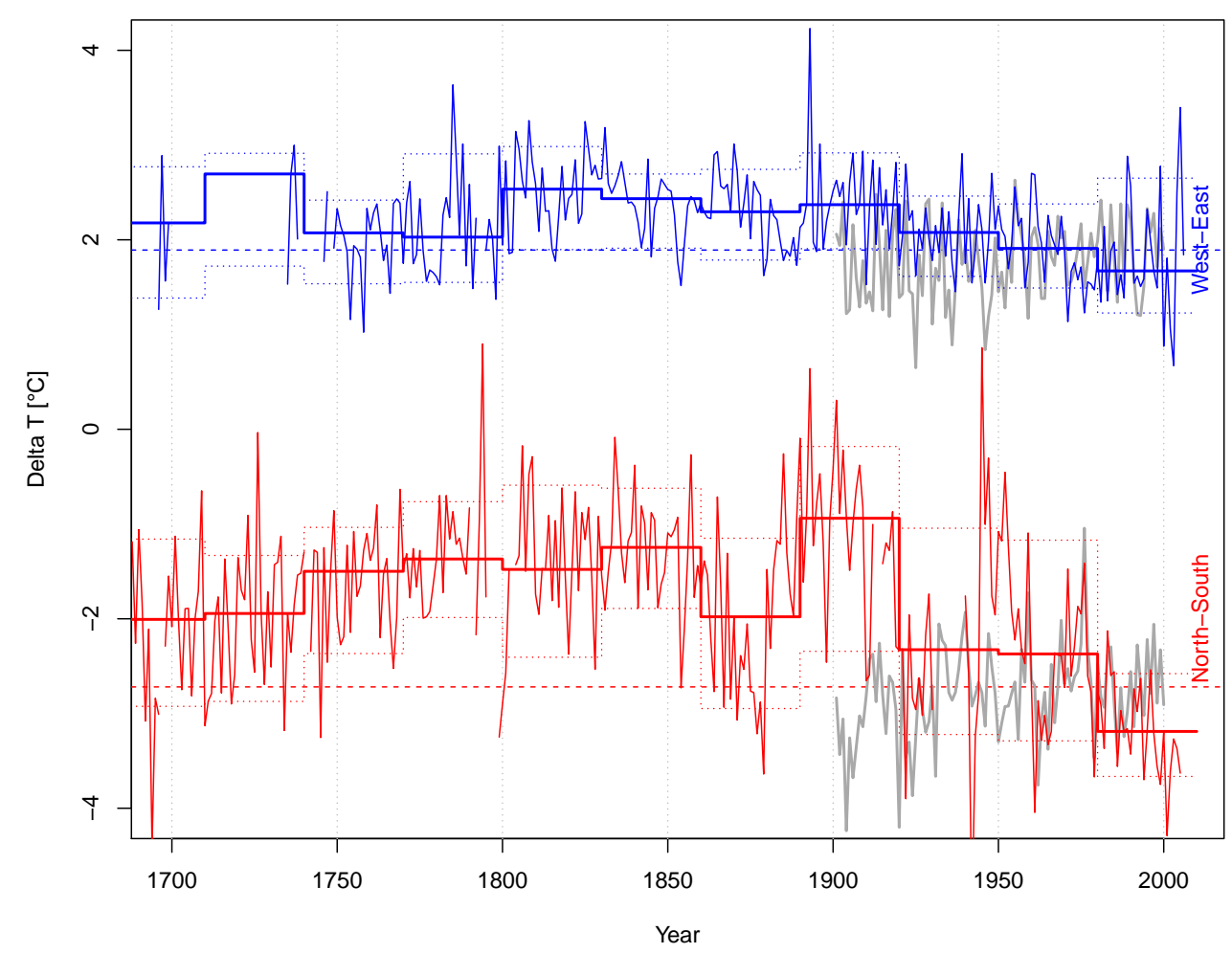

Fig. 3. Differences between North and South (N-S: red line), and West and East (W-E: blue line) reconstructions of mid-March-August temperatures. Colored (red and blue) step lines correspond to 10th, median and 90th quantiles of variations over non overlapping windows of 30 yr. Grey lines refer to the April to August temperature differences between Bordeaux and Dijon (W-E), and Paris and Orange (N-S). The horizontal dotted lines represent the mean of the observed temperature gradients.

available GHD series during this period in this area (Fig. 1, because of several particular events, such as the disappearance of the bans de vendanges, the vineyard reconstruction after phylloxera epidemics from 1867 to 1898 (Direction Departementale de l'Agriculture (DDA) and Service Central des Enquêtes et Études Statistiques (SCEES), 1983; Branas, 1974), and the 1910 mildew outbreak.

\subsection{Temperature gradient reconstructions}

We computed the differences between temperature reconstructions from the North and the South, and from the West and the East. As specified in Fig. 2, the northern region includes Île-de-France and Alsace, the southern region includes Rhône Valley, the western region includes Bordeaux and Val de Loire, and the eastern region includes Burgundy, Jura and Switzerland. Those differences approximate North-South and West-East temperature gradients in France (Fig. 3). We determined confidence intervals over non-overlapping periods of $30 \mathrm{yr}$ by computing the 10th and 90th percentiles of the reconstructed gradient within each period, bracketing the local median. For a Gaussian variable, this corresponds to $\sim 1.3$ standard deviation intervals. Those confidence intervals allow estimating the significance of interdecadal changes in the temperature gradient.
The reconstructed gradients can be compared to differences of instrumental temperature anomalies. The correlations are significant but rather weak $(r=0.21, p$-value $=0.13$ for N-S gradients, and $r=0.45, p$-value $=10^{-3}$ for W-E gradients); the means $\left(m=-2.5^{\circ} \mathrm{C}\right.$ for N-S and $\sim 1.9^{\circ} \mathrm{C}$ for W-E) and standard deviations (standard deviation $\sim 0.5^{\circ} \mathrm{C}$ for $\mathrm{N}-\mathrm{S}$ and $\sim 0.4^{\circ} \mathrm{C}$ for W-E) for $1950-2000$ are both roughly correctly reproduced ( $p$-value $=0.01$ for a two-sided Kolmogorov-Smirnov test).

Divergences between the observed and reconstructed N$\mathrm{S}$ gradient appear before 1960. The discrepancy between 1900 and 1920 is probably due to the already mentioned lower number of GHD series during this period in southern vineyards. Our reconstruction yields variations for the North-South (N-S) temperature gradient, with values ranging from $-4{ }^{\circ} \mathrm{C}$ to $0{ }^{\circ} \mathrm{C}$. The gradient shows a long period without large breakpoints, between $-2^{\circ} \mathrm{C}$ and $-1{ }^{\circ} \mathrm{C}$ on $30 \mathrm{yr}-$ average, from 1700 to 1850 , followed by an important decreasing trend up to 1880 . It yields large variations at the end of the 17 th century (from -4 to $-1^{\circ} \mathrm{C}$ ) and a decreasing trend since the 1940s. This gradient is at its reconstructed minimum at present, with an average of approx. $-3.2^{\circ} \mathrm{C}$ between 1980 and 2006. The West-East (W-E) temperature gradient does not have such clear-cut variations, and its 

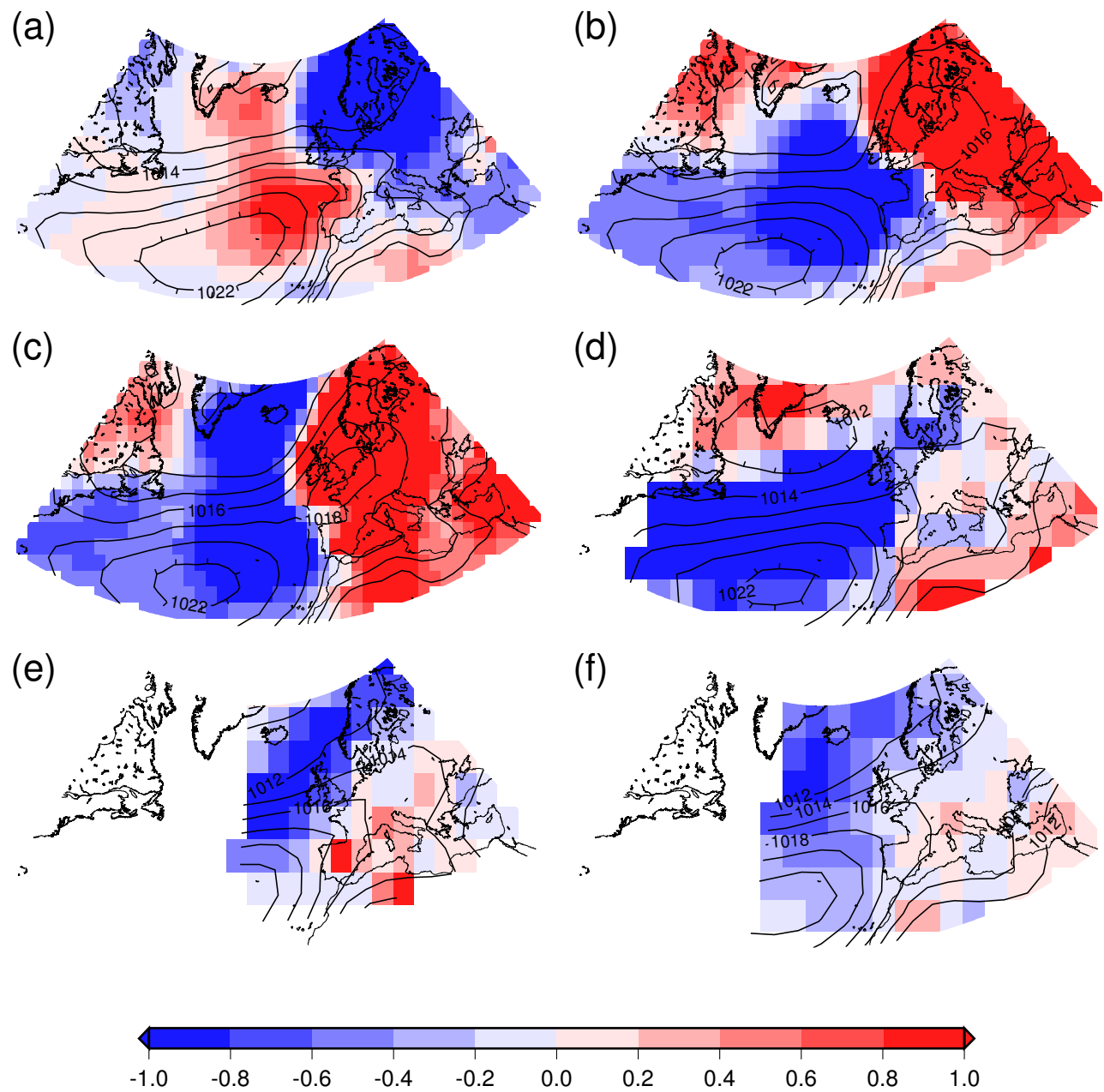

Fig. 4. (a-c): inferred sea level pressure (SLP) patterns from reconstructed temperature anomaly gradients. (a): steep N-S temperature anomaly gradients (dTNS $<-4 \mathrm{~K}$ ); (b) small N-S temperature anomaly gradients (dTNS $>-2 \mathrm{~K}$ ); (c) small N-S (dTNS $>-2 \mathrm{~K}$ ) and large W-E temperature gradients (dTWE $>2$ K). (d) average SLP for the 1890-1910 period from the EMULATE dataset (Ansell et al., 2006). (e) April to August SLP reconstruction between 1750 and 1850 by Luterbacher et al. (2002). (f) April to August SLP reconstruction between 1750 and 1850 of Kuettel et al. (2010). Isoline contours indicate SLP patterns, with $2 \mathrm{hPa}$ increments. Colors indicate SLP anomalies (in hPa).

amplitude is weaker than the North-South gradient. It was, on average, a little larger during the 19th century and showed oscillations with an amplitude of $\sim 2{ }^{\circ} \mathrm{C}$ during the 20th century. Thus, rather than discussing year-to-year variations of temperature gradients that are not meaningful, we focus on persistent multi-decadal states of the reconstructed gradients, especially before the 20th century.

\subsection{Atmospheric flow inference}

The methodology to derive a regional temperature reconstruction from pressure data generally exploits relations between pressure gradients and temperature due to the advection of heat. The fraction of temperature variations explained by atmospheric flow is significant over Western Europe (Vautard and Yiou, 2009). Conversely, a thermal wind approximation (e.g. Eq. 7.6b in Peixoto and Oort, 1992) suggests that temperature gradients can be used to derive atmospheric flows. This is the motivation of the use of the four cardinal region reconstructions to infer atmospheric circulation pattern reconstructions.

The reconstructed $\mathrm{N}-\mathrm{S}$ temperature difference can be above $-2{ }^{\circ} \mathrm{C}$ (i.e. flat gradient). Conversely, the N-S temperature gradients averaged over AMJJA during the second half of the 20th century (covered by the NCEP reanalysis data) are rather steep $\left(\sim-3^{\circ} \mathrm{C}\right.$, Fig. 3). Thus, the AMJJA averages of SLP in NCEP reanalysis and corresponding observed temperatures cannot sample the values that can be reached by the reconstructed temperature gradients prior to the 20th century. We used the daily data for which daily (observed) temperature gradients can be "flat" or "steep", in order to sample the whole range of possible values of the gradients and associated pressure patterns. 


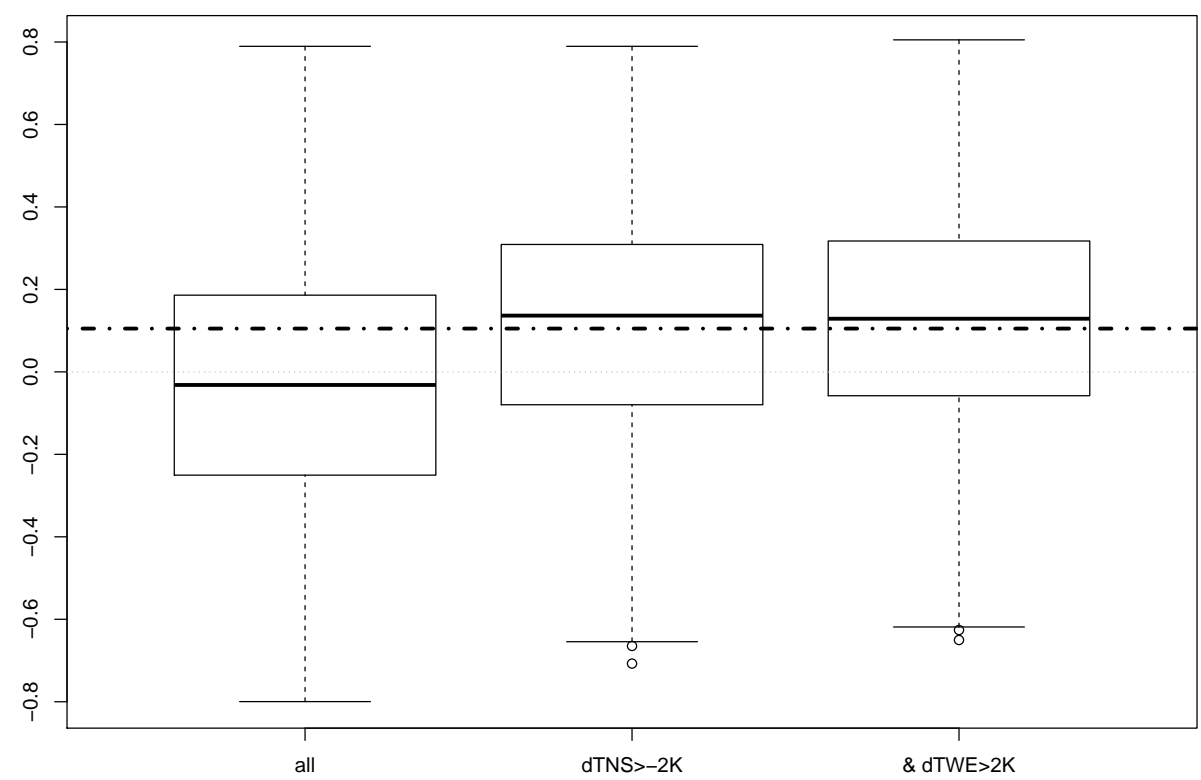

Fig. 5. Box-and-whisker plots of spatial correlations between the composite pattern of sea level pressure (from NCEP reanalysis) obtained for days of high North-South temperature difference between April and August: all days ("All”), days with N-S temperature differences larger than $-2 \mathrm{~K}$ ("dTNS $>-1.5 \mathrm{~K}$ "), days with $\mathrm{N}$-S temperature differences larger than $-2 \mathrm{~K}$ and W-E temperature differences larger than $1 \mathrm{~K}$ ("\& dTWE $>2 \mathrm{~K}$ "). The dash dotted horizontal line is the correlation and has a $p$-value under $10^{-3}$.

From recently observed temperatures (between 1950 and 2007), we determined the days for which the N-S temperature difference exceeds $-2{ }^{\circ} \mathrm{C}$ during the Mid-March to August period, which corresponds to the period of our reconstructed temperature. We then computed composite sea level pressure (SLP) from the National Centers for Environmental Prediction (NCEP) reanalysis data (Kalnay et al., 1996) to obtain the prevailing atmospheric circulation for high NorthSouth temperature anomaly gradients. When steep N-S gradients $\left(<-3{ }^{\circ} \mathrm{C}\right)$ occured, e.g. between 1950 and 2000, the circulation yielded a zonal flow pattern which was consistent with a frequent positive phase of the North Atlantic Oscillation (Fig. 4a) and strong thermal wind (Marshall and Plumb, 2008). When the N-S gradient is weaker $\left(>-2{ }^{\circ} \mathrm{C}\right)$, the atmospheric circulation corresponds to a blocking pattern (Rex, 1950) (Fig. 4b, c).

We checked from the NCEP reanalysis SLP (Kalnay et al., 1996) that the circulation patterns corresponding to a high temperature gradient are mutually consistent, and correspond to a blocking situation with an anticyclonic pattern over Western Europe. This was done by computing the spatial correlation between the circulation pattern of each day (between 1948 and 2004) with a temperature gradient above $-2{ }^{\circ} \mathrm{C}$ and the composite circulation pattern and verifying that the correlations are positive and significant (Fig. 5). The box-and-whisker plot in Fig. 5 shows that more than $70 \%$ of the days with a temperature gradient above $2{ }^{\circ} \mathrm{C}$ have a positive correlation with the composite SLP pattern corresponding to this temperature gradient (shown in Fig. 4b). More- over, $60 \%$ of those days have a significant correlation with the composite SLP pattern. This shows that this composite circulation pattern has a meaningful signature on the temperature gradient and emphasizes the discriminating power of the North-South temperature gradient for sea level pressure. The moderate score is explained by the large intra-seasonal atmospheric variability (Cassou et al., 2005; Philipp et al., 2007). This correlation is accentuated if the constraint of a large West-East gradient is added, although the W-E temperature gradient alone yield barely any discriminating power on the circulation.

We verified that the pattern is coherent with atmospheric circulation estimates by comparing the results with the EMULATE gridded sea level pressure (SLP) dataset (Ansell et al., 2006) over the 1890-1910 period, during which the N-S temperature gradient during the warm season was low (Fig. 4d). The EMULATE dataset suggests a relative anticyclonic pattern over Western Europe, but much weaker and spatially far less extensive than the one inferred from the reconstructions in Figs. 4b-c. The associated low pressure anomaly structure immediately west of Western Europe is much more like that inferred from the reconstructions, suggesting the existence of a blocking situation in terms of the relative E-W pressure gradient. Hence, we were able to infer a dominating atmospheric circulation pattern corresponding to high and low values of temperature gradients over the cardinal regions of France (Fig. 4). This result is consistent with reconstructions that infer more continental circulation during the Little Ice Age (Jacobeit et al., 2003; Folland et al., 2009). 
We compared the April to August SLP pattern reconstruction between 1750 and 1850 , during which the N-S temperature gradient is relatively shallow in our reconstruction, with the SLP reconstructions of Kuettel et al. (2010) and Luterbacher et al. (2002). Those two reconstructions are broadly consistent during that period in showing a slight increase of SLP anomalies over Western Europe (Fig. 4e-f). The pattern of our reconstruction (Fig. 4b) is more pronounced over Europe than the reconstructions (Fig. 4d-f) of Ansell et al. (2006), Kuettel et al. (2010), and Luterbacher et al. (2002), but the isolines of SLP over Western Europe suggest a weakened atmospheric circulation in all cases during periods of weak temperature gradients $\left(\mathrm{dTNS}>2{ }^{\circ} \mathrm{C}\right.$ ).

This synoptic weather pattern lasts from a few days to several weeks (Michelangeli and Vautard, 1998). It does not exclude that zonal atmospheric patterns, such as the phases of the North Atlantic Oscillation, occur and bring moist air to Western Europe. Hence, we insist on the caveat that our inferred SLP pattern is the one that is most likely given a seasonal temperature gradient reconstruction. This inference cannot be extended to subseasonal variability (Michelangeli et al., 1995; Corti et al., 1999) in a trivial way.

\section{Discussion and conclusion}

This paper has explored the potential for grape harvest dates to reconstruct spatial information of past climate variability. Such data contain a fine network that gives access to regional climate variations. The temperature reconstructions show shifts in temperature North-South gradients. Such shifts are identified on multi-decadal periods. They can have a mean amplitude as high as $1^{\circ} \mathrm{C}$. We found no evidence in historical agronomical documents of wine growing practice changes in those regions and hence assumed that their origin is a climate change. This trend is also coherent with other independent proxy reconstructions (Guiot et al., 2005).

We proposed a methodology to reconstruct mean atmospheric circulation patterns. This reconstruction is based on the present observation that high and low North-South temperature gradients are connected to synoptic atmospheric patterns. Hence, we were able to infer an atmospheric circulation pattern that is compatible with high and low values of North-South temperature gradients. This approach is similar to the method of analogues (Vautard and Yiou, 2009), and we also propose a test of the significance of the inferred circulation. The caveat of this approach is that the circulation inference is a composite that is only valid for the multidecadal periods for which the sample size of high (or low) temperature gradient values are observed.

We find that a likely atmospheric pattern that prevailed during periods of relatively "flat" temperature gradient, especially between 1700 and $1850 \mathrm{AD}$ is a blocking that brings continental flow over Western Europe. This pattern amplitude is more pronounced than what is inferred in other re- constructions, although it is qualitatively consistent (with positive SLP anomalies over Western Europe). This finding advocates a description of atmospheric variability that goes beyond the phases of the North Atlantic Oscillation and takes weather regimes into account (Michelangeli et al., 1995; Yiou and Nogaj, 2004; Yiou et al., 2008).

ThEse results will be used to constrain the local scales of climate simulations of the last millennium.

Finally, our results emphasize the importance of interdisciplinary investigations to assess the sources of uncertainties in climate reconstructions.

\section{Supplementary material related to this article is available online at: http://www.clim-past.net/8/577/2012/ cp-8-577-2012-supplement.pdf.}

Acknowledgements. This work was supported by the French ANR OPHELIE project. We thank the INRA Agroclim research group for providing the climate observation database used with the STICS crop model in this study. We thank the three anonymous reviewers for constructive comments.

Edited by: J. Luterbacher

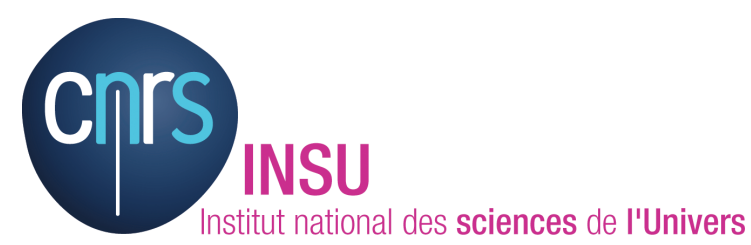

The publication of this article is financed by CNRS-INSU.

\section{References}

Alonso de Herrera, G.: Agricultura general, version completed in 1813 by the "Real Sociedad Economica Matritense", 544 pp., 1513.

Ansell, T., Jones, P., Allan, R., Lister, D., Parker, D., Brunet, M., Moberg, A., Jacobeit, J., Brohan, P., Rayner, N., Aguilar, E., Alexandersson, H., Barriendos, M., Brandsma, T., Cox, N., Della-Marta, P., Drebs, A., Founda, D., Gerstengarbe, F., Hickey, K., Jonsson, T., Luterbacher, J., Nordli, O., Oesterle, H., Petrakis, M., Philipp, A., Rodwell, M., Saladie, O., Sigro, J., Slonosky, V., Srnec, L., Swail, V., Garcia-Suarez, A., Tuomenvirta, H., Wang, X., Wanner, H., Werner, P., Wheeler, D., and Xoplaki, E.: Daily mean sea level pressure reconstructions for the European-north Atlantic region for the period 1850-2003, J. Climate, 19, 2717-2742, 2006.

Bidet, N.: Traité sur la nature et sur la culture de la vigne, sur le vin, la façon de le faire et la manière de le bien gouverner, I, 2 Edn., Savoye, Paris, 562 pp., 1759a.

Bidet, N.: Traité sur la nature et sur la culture de la vigne, sur le vin, la façon de le faire et la manière de le bien gouverner, II, 2 Edn., Savoye, Paris, 326 pp., 1759b. 
Bidet, N.: Traité sur la nature et sur la culture de la vigne; sur le vin, la façon de le faire, et la manière de le bien gouverner, A l'usage des différents vignobles du royaume de france, Savoye, Paris, 562 pp., 1759c.

Branas, J.: Viticulture, Déhan, Montpellier (France), Déhan, 990 pp., 1974.

Brazdil, R., Pfister, C., Wanner, H., Von Storch, H., and Luterbacher, J.: Historical climatology in Europe - the state of the art, Clim. Change, 70, 363-430, 2005.

Briffa, K. R., Wigley, T., Jones, P., Pilcher, J., and Hughes, M.: Patterns of tree-growth and related pressure variability in Europe, Dendrochnologia, 5, 35-59, 1987.

Briffa, K. R., Jones, P. D., Wigley, T., Pilcher, J., and Baillie, M.: Climate reconstruction from tree rings. 2. Spatial reconstruction of summer mean sea-level pressure over great britain, J. Climatol., 6, 1-15, 1986.

Brisson, N., Mary, B., Ripoche, D., Jeuffroy, M. H., Ruget, F., Nicoullaud, B., Gate, P., Devienne-Barret, F., Antonioletti, R., Durr, C., Richard, G., Beaudoin, N., Recous, S., Tayot, X., Plenet, D., Cellier, P., Machet, J. M., Meynard, J. M., and Delecolle, R.: Stics: A generic model for the simulation of crops and their water and nitrogen balances. I. Theory and parameterization applied to wheat and corn, Agronomie, 18, 311-346, 1998.

Brisson, N., Ruget, F., Gate, P., Lorgeau, J., Nicoullaud, B., Tayot, X., Plenet, D., Jeuffroy, M. H., Bouthier, A., Ripoche, D., Mary, B., and Justes, E.: Stics: A generic model for simulating crops and their water and nitrogen balances. II. Model validation for wheat and maize, Agronomie, 22, 69-92, doi:10.1051/agro:2001005, 2002.

Brisson, N., Gary, C., Justes, E., Roche, R., Mary, B., Ripoche, D., Zimmer, D., Sierra, J., Bertuzzi, P., Burger, P., Bussiere, F., Cabidoche, Y. M., Cellier, P., Debaeke, P., Gaudillere, J. P., Henault, C., Maraux, F., Seguin, B., and Sinoquet, H.: An overview of the crop model STICS, Eur. J. Agron., 18, 309-332, 2003.

Brisson, N., Launay, M., Mary, B., and Beaudoin, N.: Conceptual basis, formalisations and parameterization of the STICS crop model., Quae Edn., Paris, 297 pp., 2009.

Cassou, C., Terray, L., and Phillips, A.: Tropical Atlantic influence on European heat waves, J. Climate, 18, 2805-2811, 2005.

Caussinus, H. and Mestre, O.: Detection and correction of artificial shifts in climate series, J. Roy. Stat. Soc. C-App., 53, 405-425, 2004.

Champagnol, F.: Eléments de physiologie de la vigne et de viticulture générale, F. Champagnol, Prades-le-Lez, 351 pp., 1984.

Chaptal, J.-A.: L'art de faire, gouverner et perfectionner les vins, Delalain fils, Paris, 204 pp., 1801.

Chuine, I., Yiou, P., Viovy, N., Seguin, B., Daux, V., and Ladurie, E.: Historical phenology: Grape ripening as a past climate indicator, Nature, 432, 289-290, 2004.

Corti, S., Molteni, F., and Palmer, T. N.: Signature of recent climate change in frequencies of natural atmospheric circulation regimes, Nature, 398, 799-802, 1999.

Daux, V., Garcia de Cortazar-Atauri, I., Yiou, P., Chuine, I., Garnier, E., Le Roy Ladurie, E., Mestre, O., and Tardaguila, J.: An open-database of Grape Harvest dates for climate research: data description and quality assessment, Clim. Past Discuss., 7, 38233858, doi:10.5194/cpd-7-3823-2011, 2011. de Herrera, G. A. and Real Sociedad Económica Matritense: Agricultura general corregida segun el testo original de la primera edicion publicada en 1513por el mismo autor y adicionada por la real sociedad económica matritense, Imprenta Real, Madrid, 551 pp., 1818.

de La Poix de Fréminville, E.: Dictionnaire ou traité de la police générale des villes, bourgs, paroisses et seigneuries de la campagne, Paris, 588 pp., 1758.

de Serres, O.: Le théâtre d'agriculture et mesnage des champs, Paris, 937 pp., 1600.

Direction Departementale de l'Agriculture (DDA), and Service Central des Enquêtes et Études Statistiques (SCEES): La vigne dans le vaucluse: Enquête pour le rencesement général agricole - viticulture, in, edited by: Vaucluse, Direction Departementale de l'Agriculture du Vaucluse, 50 pp., 1983.

Estienne, C. and Libeault, J.: L'agriculture et maison rustique, JeanBaptiste Gimeaux Lyon, 930 pp., 1589.

Estienne, C. and Liebault, J.: L'agriculture et la maison rustique, Jacques Du-Puys, 930 pp., 1589.

Folland, C. K., Knight, J., Linderholm, H. W., Fereday, D., Ineson, S., and Hurrell, J. W.: The summer north Atlantic oscillation: Past, present, and future, J. Climate, 22, 1082-1103, 2009.

Galet, P.: Cepages et vignobles de france, Imprimerie P. Dehan, Montpellier, 1956.

Galet, P.: Les vignobles de France. Volume 1. Méditerranée, RhôneAlpes, Bourgogne, Franche-Comté, Alsace-Lorraine, 2 Edn., Cépages et vignobles de France, Ed. Tec \& doc, Paris Londres New York, 1285 pp., 2004.

Galet, P.: Les vignobles de France volume 2: Champagne-Ardenne, nord-Picardie, Île-Defrance, nord-ouest, centre, centre-ouest, Aquitaine ou sud-ouest, centre-sud, 2 Edn., Cépages et vignobles de France, Ed. Tec \& doc, Paris Londres New York, 1275 pp. 2006.

García de Cortázar-Atauri, I.: Adaptation du modèle stics à la vigne (vitis vinifera 1.). Utilisation dans le cadre d'une étude du changement climatique à l'échelle de la France, Ph.D. Thesis, Agroclim - INRA, Ecole Supérieur Nationale d'Agronomie de Montpellier, Montpellier, 292 pp., 2006.

García de Cortázar-Atauri, I., Brisson, N., and Gaudillere, J. P.: Performance of several models for predicting budburst date of grapevine (vitis vinifera 1.), Int. J. Biometeorol., 53, 317-326, 2009a.

García de Cortázar-Atauri, I., Brisson, N., Ollat, N., Jacquet, O., and Payan, J. C.: Asynchronous dynamics of grapevine (vitis vinifera) maturation: Experimental study for a modelling approach, J. Int. Sci. Vigne Vin, 43, 83-97, 2009 b.

García de Cortázar-Atauri, I., Daux, V., Garnier, E., Yiou, P., Viovy, N., Seguin, B., Boursiquot, J. M., Parker, A., van Leeuwen, C., and Chuine, I.: An assessment of error sources when using grape harvest date for past climate reconstruction, Holocene, 10, 465479, 2010.

Garnier, E., Daux, V., Yiou, P., and García de Cortázar-Atauri, I.: Grapevine harvest dates in besançon (france) between 1525 and 1847: Social outcomes or climatic evidence?, Clim. Change, 104, 703-727, doi:10.1007/s10584-010-9810-0, 2010.

Gautier, A.: Sophistication et analyse des vins, 4 ed., J.-B. Baillière et Fils, Paris, 412 pp., 1891.

Gay-Lussac, L. J.: Cours de chimie comprenant l'histoire des sels, la chimie végétale et animale, Vol II., Pichon et Didier, Paris, 
536 pp., 1828.

Guyot, J.: Etude des vignobles de France pour servir à l'enseignement mutuel de la viticulture et de la vinification françaises. Ii. Régions du centre-sud, de l'est et de l'ouest, Impr. impériale, Paris, 739 pp., 1868a.

Guyot, J.: Etude des vignobles de France pour servir à l'enseignement mutuel de la viticulture et de la vinification françaises. Iii. Régions du centre-nord, du nord et du nord-ouest., Impr. impériale, Paris, 710 pp., 1868b.

Guyot, J.: Etude des vignobles de France pour servir à l'enseignement mutuel de la viticulture et de la vinification françaises. I. Régions du sud-est et du sud-ouest, Impr. impériale, Paris, 609 pp., 1868c.

Guyot, J.: Etude des vignobles de France pour servir à l'enseignement mutuel de la viticulture et de la vinification françaises. Tome ii : Régions du centre-sud, de l'est et de l'ouest, Impr. impériale, Paris, 1449 pp., $1868 d$.

Guiot, J., Nicault, A., Rathgeber, C., Edouard, J. L., Guibal, E., Pichard, G., and Till, C.: Last-millennium summer-temperature variations in western Europe based on proxy data, Holocene, 15, 489-500, 2005.

Holt, H. E., Francis, I. L., Field, J., Herderich, M. J., and Iland, P. G.: Relationships between berry size, berry phenolic composition and wine quality scores for cabernet sauvignon (vitis vinifera 1.) from different pruning treatments and different vintages, Aust. J. Grape Wine R., 14, 191-202, doi:10.1111/j.17550238.2008.00019.x, 2008.

Jacobeit, J., Wanner, H., Luterbacher, J., Beck, C., Philipp, A., and Sturm, K.: Atmospheric circulation variability in the northAtlantic-European area since the mid-seventeenth century, Clim. Dynam., 20, 341-352, 2003.

Jones, G. V.: Winegrape phenology, in: Phenology: An integrative environmental science, edited by: Schwartz, M. D., Tasks for vegetation science Kluwer Press, Dordrecht 523-539, 2003.

Jones, P., Davies, T., Lister, D., Slonosky, V., Jonsson, T., Barring, L., Jonsson, P., Maheras, P., Kolyva-Machera, F., Barriendos, M., Martin-Vide, J., Rodriguez, R., Alcoforado, M., Wanner, H., Pfister, C., Luterbacher, J., Rickli, R., Schuepbach, E., Kaas, E., Schmith, T., Jacobeit, J., and Beck, C.: Monthly mean pressure reconstructions for Europe for the 1780-1995 period, Int. J. Climatol., 19, 347-364, 1999.

Jullien, A. and Jullien, C.-E.: Topographie de tous les vignobles connus., Vve Bouchard-Huzard, Paris, 867 pp., 1866.

Kalnay, E., Kanamitsu, M., Kistler, R., Collins, W., Deaven, D., Gandin, L., Iredell, M., Saha, S., White, G., Woollen, J., Zhu, Y., Chelliah, M., Ebisuzaki, W., Higgins, W., Janowiak, J., Mo, K., Ropelewski, C., Wang, J., Leetmaa, A., Reynolds, R., Jenne, R., and Joseph, D.: The NCEP/NCAR 40-year reanalysis project, B. Am. Meteorol. Soc., 77, 437-471, 1996.

Klein-Tank, A., Wijngaard, J., Konnen, G., Bohm, R., Demaree, G., Gocheva, A., Mileta, M., Pashiardis, S., Hejkrlik, L., KernHansen, C., Heino, R., Bessemoulin, P., Muller-Westermeier, G., Tzanakou, M., Szalai, S., Palsdottir, T., Fitzgerald, D., Rubin, S., Capaldo, M., Maugeri, M., Leitass, A., Bukantis, A., Aberfeld, R., Van Engelen, A., Forland, E., Mietus, M., Coelho, F., Mares, C., Razuvaev, V., Nieplova, E., Cegnar, T., Lopez, J., Dahlstrom, B., Moberg, A., Kirchhofer, W., Ceylan, A., Pachaliuk, O., Alexander, L., and Petrovic, P.: Daily dataset of 20thcentury surface air temperature and precipitation series for the
European climate assessment, Int. J. Climatol., 22, 1441-1453, 2002.

Kuettel, M., Xoplaki, E., Gallego, D., Luterbacher, J., GarciaHerrera, R., Allan, R., Barriendos, M., Jones, P., Wheeler, D., and Wanner, H.: The importance of ship log data: Reconstructing north Atlantic, European and Mediterranean sea level pressure fields back to 1750, Clim. Dynam., 34, 1115-1128, 2010.

Laudier, M.: Nouveau manuel complet des marchands de vins, des débitants de boissons et du jaugeage contenant 1 la théorie élémentaire de la science des commerçants en vins, Nouv. Ed., Manuels-roret, Roret, Paris, 520 pp., 1852.

Le Roy Ladurie, E.: Times of feast, times of famine: A history of climate since the year 1000, Doubleday, Garden City, N.Y., 426 pp., 1971.

Luterbacher, J., Schmutz, C., Gyalistras, D., Xoplaki, E., and Wanner, H.: Reconstruction of monthly NAO and eu indices back to AD 1675, Geophys. Res. Lett., 26, 2745-2748, 1999.

Luterbacher, J., Rickli, R., Tinguely, C., Xoplaki, E., Schupbach, E., Dietrich, D., Husler, J., Ambuhl, M., Pfister, C., Beeli, P., Dietrich, U., Dannecker, A., Davies, T., Jones, P., Slonosky, V., Ogilvie, A., Maheras, P., Kolyva-Machera, F., Martin-Vide, J., Barriendos, M., Alcoforado, M., Nunes, M., Jonsson, T., Glaser, R., Jacobeit, J., Beck, C., Philipp, A., Beyer, U., Kaas, E., Schmith, T., Barring, L., Jonsson, P., Racz, L., and Wanner, H.: Monthly mean pressure reconstruction for the late Maunder minimum period (ad 1675-1715), Int. J. Climatol., 20, 1049-1066, 2000.

Luterbacher, J., Xoplaki, E., Dietrich, D., Rickli, R., Jacobeit, J., Beck, C., Gyalistras, D., Schmutz, C., and Wanner, H.: Reconstruction of sea level pressure fields over the eastern north Atlantic and Europe back to 1500, Clim. Dynam., 18, 545-561, 2002.

Marshall, J. and Plumb, R. A.: Atmosphere, ocean, and climate dynamics: An introductory text, Elsevier Academic Press, Amsterdam, Boston, 319 pp., 2008.

Maumene, E. J.: Indications théoriques et pratiques sur le travail des vins et en particulier sur celui des vins mousseux, edited by: Sadras, V. O., V. Masson, Paris, 634 pp., 1858.

Maurer, C., Koch, E., Hammerl, C., Hammerl, T., and Pokorny, E.: Bacchus temperature reconstruction for the period 16th to 18th centuries from viennese and klosterneuburg grape harvest dates, J. Geophys. Res.-Atmos., 114, D22106, doi:10.1029/2009JD011730, 2009.

Meier, N., Rutishauser, T., Pfister, C., Wanner, H., and Luterbacher, J.: Grape harvest dates as a proxy for swiss april to august temperature reconstructions back to ad 1480, Geophys. Res. Lett., 34, L20705, doi:10.1029/2007GL031381, 2007.

Michelangeli, P. A., Vautard, R., and Legras, B.: Weather regimes: Recurrence and quasi-stationarity, J. Atmos. Sci., 52, $1237-$ 1256, 1995.

Michelangeli, P. A. and Vautard, R.: The dynamics of euro-atlantic blocking onsets, Q. J. Roy. Meteorol. Soc., 124, 1045-1070, 1998.

Nendel, C.: Grapevine bud break prediction for cool winter climates, Int. J. Biometeorol., 1-11, 2009.

Odart, A. P.: Ampélographie, ou traité des cépages les plus estimés dans tous les vignobles de quelque renom, Bixio, Paris, 436 pp., 1845.

Parker, A. K., García de Cortázar-Atauri, I., van Leeuwen, C., and 
Chuine, I.: General phenological model to characterise the timing of flowering and veraison of vitis vinifera 1., Aust. J. Grape Wine R., 17, 206-216, doi:10.1111/j.1755-0238.2011.00140.x, 2011.

Peixoto, J. P., and Oort, A. H.: Physics of climate, American Institute of Physics, New York, xxxix, 520 pp., 1992.

Philipp, A., Della-Marta, P. M., Jacobeit, J., Fereday, D. R., Jones, P. D., Moberg, A., and Wanner, H.: Long-term variability of daily north Atlantic-European pressure patterns since 1850 classified by simulated annealing clustering, J. Climate, 20, 4065-4095, 2007.

Pocquet de Livonnière, C.: Traité des fiefs, Jean-Baptiste Coignard, Paris, 714 pp., 1733.

Rendu, V.: Ampélographie française comprenant la statistique, la description des meilleurs cépages, l'analyse chimique du sol et les procédés de culture et de vinification des principaux vignobles de la france, V. Masson, Paris, 576 pp., 1857.

Rex, D. F.: Blocking action in the middle troposphere and its effect upon regional climate, Part I, Tellus, 2, 196-211, 1950.

Salvaing de Boissieu, D.: De l'usage des fiefs et autres droits seigneuriaux en Dauphiné, François Feronce, Grenoble, 581 pp., 1664.

Slonosky, V. C., Jones, P. D., and Davies, T. D.: Atmospheric circulation and surface temperature in Europe from the 18th century to 1995, Int. J. Climatol., 21, 63-75, 2001.
Souriau, A. and Yiou, P.: Grape harvest dates for checking NAO paleoreconstructions, Geophys. Res. Lett., 28, 3895-3898, 2001.

Trouet, V., Esper, J., Graham, N. E., Baker, A., Scourse, J. D., and Frank, D. C.: Persistent positive north Atlantic oscillation mode dominated the medieval climate anomaly, Science, 324, 78-80, 2009.

Van Leeuwen, C. and Seguin, G.: The concept of terroir in viticulture, J. Wine Research, 17, 1-10, 2006.

Vautard, R. and Yiou, P.: Control of recent European surface climate change by atmospheric flow, Geophys. Res. Lett., 36, L22702, doi:10.1029/2009GL040480, 2009.

Wang, E. L. and Engel, T.: Simulation of phenological development of wheat crops, Agricultural Systems, 58, 1-24, 1998.

Williams, D. W., Andris, H. L., Beede, R. H., Luvisi, D. A., Norton, M. V. K., and Williams, L. E.: Validation of a model for the growth and development of the thompson seedless grapevine. 2 . Phenology, Am. J. Enol. Viticult., 36, 283-289, 1985.

Yiou, P. and Nogaj, M.: Extreme climatic events and weather regimes over the north Atlantic: When and where?, Geophys. Res. Lett., 31, L07202, doi:10.1029/2003GL019119, 2004.

Yiou, P., Goubanova, K., Li, Z. X., and Nogaj, M.: Weather regime dependence of extreme value statistics for summer temperature and precipitation, Nonlin. Proc. Geophys., 15, 365-378, 2008. 